\title{
Front Matter: Volume 10010
}

, "Front Matter: Volume 10010," Proc. SPIE 10010, Advanced Topics in Optoelectronics, Microelectronics, and Nanotechnologies VIII, 1001001 (20 December 2016); doi: 10.1117/12.2257302

SPIE Event: Advanced Topics in Optoelectronics, Microelectronics, and SPIE. Nanotechnologies 2016, 2016, Constanta, Romania 


\title{
Advanced Topics in Optoelectronics, Microelectronics, and Nanotechnologies VIII
}

\author{
Marian Vladescu \\ Razvan Tamas \\ Ionica Cristea \\ Editors
}

25-28 September 2016

Constanta, Romania

Organized by

Politehnica University of Bucharest - Optoelectronics Research Center (UPB-CCO)

Maritime University of Constanta (Romania)

Sponsored by

Romanian Ministry of Education and Research (Romania)

National Authority for Scientific Research and Innovation (Romania)

Politehnica University of Bucharest (Romania)

Maritime University of Constanta (Romania)

Agilrom Scientific (Romania)

ADVI TECH Consulting SRL (Romania)

Cooperationg Organization and Publisher

SPIE 
The papers in this volume were part of the technical conference cited on the cover and title page. Papers were selected and subject to review by the editors and conference program committee. Some conference presentations may not be available for publication. Additional papers and presentation recordings may be available online in the SPIE Digital Library at SPIEDigitallibrary.org.

The papers reflect the work and thoughts of the authors and are published herein as submitted. The publisher is not responsible for the validity of the information or for any outcomes resulting from reliance thereon.

Please use the following format to cite material from these proceedings:

Author(s), "Title of Paper," in Advanced Topics in Optoelectronics, Microelectronics, and Nanotechnologies VIII, edited by Marian Vladescu, Razvan Tamas, Ionica Cristea, Proceedings of SPIE Vol. 10010 (SPIE, Bellingham, WA, 2016) Seven-digit Article CID Number.

ISSN: 0277-786X

ISSN: 1996-786X (electronic)

ISBN: 9781510604247

ISBN: 9781510604254 (electronic)

Published by

SPIE

P.O. Box 10, Bellingham, Washington 98227-0010 USA

Telephone +1 3606763290 (Pacific Time) · Fax +1 3606471445

SPIE.org

Copyright () 2016, Society of Photo-Optical Instrumentation Engineers.

Copying of material in this book for internal or personal use, or for the internal or personal use of specific clients, beyond the fair use provisions granted by the U.S. Copyright Law is authorized by SPIE subject to payment of copying fees. The Transactional Reporting Service base fee for this volume is $\$ 18.00$ per article (or portion thereof), which should be paid directly to the Copyright Clearance Center (CCC), 222 Rosewood Drive, Danvers, MA 01923. Payment may also be made electronically through CCC Online at copyright.com. Other copying for republication, resale, advertising or promotion, or any form of systematic or multiple reproduction of any material in this book is prohibited except with permission in writing from the publisher. The CCC fee code is 0277-786X/16/\$18.00.

Printed in the United States of America.

Publication of record for individual papers is online in the SPIE Digital Library.

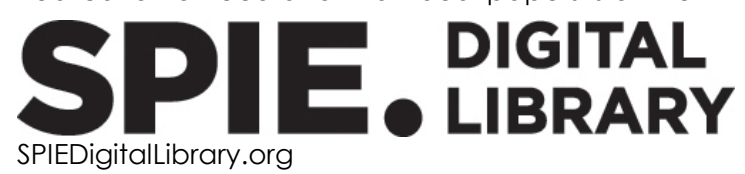

Paper Numbering: Proceedings of SPIE follow an e-First publication model. A unique citation identifier (CID) number is assigned to each article at the time of publication. Utilization of CIDs allows articles to be fully citable as soon as they are published online, and connects the same identifier to all online and print versions of the publication. SPIE uses a seven-digit CID article numbering system structured as follows:

- The first five digits correspond to the SPIE volume number.

- The last two digits indicate publication order within the volume using a Base 36 numbering system employing both numerals and letters. These two-number sets start with $00,01,02,03,04,05$, $06,07,08,09,0 A, 0 B \ldots$. OZ, followed by 10-1Z, 20-2Z, etc. The CID Number appears on each page of the manuscript. 


\title{
Contents
}

\section{Part One}

\author{
xi Authors \\ xv Conference Committees \\ xix Introduction
}

\section{PLENARY SESSION}

1001002 Interferometric correlator for acoustic radiation and underlying structural vibration (Invited Paper) [10010-42]

1001003 Plasma and particles (Invited Paper) [10010-67]

1001004 Electromagnetic and acoustic bimodality for the detection and localization of electrical arc faults (Invited Paper) [10010-158]

1001005 The use of 2D Hilbert transform for phase retrieval of speckle fields (Invited Paper) [10010-85]

1001006 On-wafer high temperature characterization system (Invited Paper) [10010-161]

1001007 Study regarding the spline interpolation accuracy of the experimentally acquired data (Invited Paper) [10010-31]

1001008 Enhanced automated plafform for 2D characterization of RFID communications (Invited Paper) [10010-155]

\section{ADVANCED MATERIALS AND NEW TECHNOLOGIES}

1001009 Synthesis and photophysics of conjugated azomethine polyrotaxanes [10010-18]

10010 OA Metal nanoparticles (other than gold or silver) prepared using plant extracts for medical applications [10010-126]

$10010 \mathrm{OB} \quad$ Ion-beam synthesis of zinc-based nanoparticles in $\mathrm{SiO}_{2}$ [10010-70]

10010 OC AC electric properties of nanocomposite $(\mathrm{FeCoZr})_{0.818}\left(\mathrm{CaF}_{2}\right)_{0.182}$ annealed in the tubular furnace [10010-71]

10010 OD Features of the formation of structure and properties of transition metals boridonitrides composite films [10010-77] 
10010 OE Structural analysis of multilayer metal nitride films CrN/MoN using electron backscatter diffraction (EBSD) [10010-80]

$10010 \mathrm{OF}$ Structural features of the multilayer nitride coatings formation [10010-81]

$100100 G$ Synthesis and characterization of novel main chain bisazobenzene polyphosphonates [10010-108]

$10010 \mathrm{OH} \quad$ New complexes of silver (I) with N-hydroxy-succinimide [10010-121]

10010 ol Low energy switching driver for printed electrochromic displays [10010-148]

10010 0J Comparative shear tests of some low temperature lead-free solder pastes [10010-150]

\section{DIFFRACTIVE, MICRO-OPTICS, AND OPTICAL SIGNAL PROCESSING}

10010 OK Cooperative entangled effects between the cavity mode components of Raman process [10010-26]

$10010 \mathrm{OL}$ Methods and means of Fourier-Stokes polarimetry and the spatial frequency filtering of phase anisotropy manifestations [10010-15]

10010 OM Methods and means of Stokes-polarimetry microscopy of optically anisotropic biological layers [10010-16]

$10010 \mathrm{ON}$ Methods and means of Fourier-Stokes polarimetry and the spatial-frequency filtering of phase anisotropy manifestations in endometriosis diagnostics [10010-50]

1001000 Influence of the coordination number $\mathrm{Z}$ on the micro-Raman spectra of ternary chalcogenide glasses [10010-48]

10010 OP Absorption and emission spectra of $\mathrm{Ga}_{1.7} \mathrm{Ge}_{25} \mathrm{As}_{8.3} \mathrm{~S}_{65}$ glasses doped with rare-earth ions [10010-56]

$100100 Q$ Energy transfer of non-equidistant radiators via the nonlinear excitation mechanism inside of an optical cavity [10010-84]

10010 OR Real-time digital holographic interferometry set-up for phase gradient study in dynamic phase objects using spatial modulator [10010-137]

SENSORS, MICROSYSTEMS, AND INSTRUMENTS

10010 OS Optical measurements for excitation of CdTe quantum dots [10010-14]

10010 OT Smart communication with LabView [10010-38]

10010 OU Design of multi-band microstrip polygonal contour filter for microwaves [10010-41]

10010 OV Development of tools and techniques for monitoring underwater artifacts [10010-39] 
10010 ow

$100100 x$

10010 OY

$100100 z$

1001010

1001011

1001012

1001013

1001014

1001015

1001016

1001017

1001018

1001019

$100101 \mathrm{~A}$

$100101 \mathrm{~B}$

$100101 C$

$100101 D$

$100101 E$

$10010 \mathrm{IF}$

$100101 G$

Universal system for the automation of test setups [10010-66]

New approach for processing data provided by an INS/GPS system onboard a vehicle [10010-69]

3D THz hyperspectrum applied in security check-in [10010-78]

Persistent scatterers detection on synthetic aperture radar images acquired by Sentinel-1 satellite [10010-82]

Terahertz spectroscopic investigations of hazardous substances [10010-83]

Assessment of illumination conditions in a single-pixel imaging configuration [10010-89]

Sensors system design for discrimination between humans and animals [10010-91]

Cyber physical systems based on cloud computing and internet of things for energy efficiency [10010-101]

Optical investigation of electromagnetic fuel atomizers [10010-113]

Investigations upon the effects of an auxiliary brake system on the working parameters of diesel engines [10010-115]

Preparation of the cast glass-coated amorphous magnetic microwires [10010-117]

Research and investigation of a communication chain on optical fiber with a Fabry-Perot power diode for the automotive industry [10010-124]

Study on determining the photometric parameters for a white LED using a light meter [10010-127]

Temperature measurements of high power LEDs [10010-131]

Data mining methods for parameters forecasting of a small solar plant [10010-135]

The influence of vibrations on time reference signals generated using quartz crystals [10010-141]

A new mechatronic set-up and technique for investigation of firearms [10010-143]

Analysis of power supply circuits for electroluminescent panels [10010-147]

Embedded systems for controlling LED matrix displays [10010-152]

Maintenance-free super-capacitor-based WSN power supply [10010-156]

Studying the thermal regime of power LEDs by using the embedded protection diode [10010-62]

$100101 \mathrm{H} \quad$ Piezoelectric devices for generating low power [10010-163] 
1001011 Microelectronics and nanotechnology, and the fractal-like structure of information, knowledge, and science [10010-6]

$100101 \mathrm{~J}$ Photoconductivity of amorphous $\mathrm{Ge}_{x} \mathrm{As}_{\mathrm{x}} \mathrm{Se}_{1-2 \mathrm{x}}$ and $\left(\mathrm{As}_{4} \mathrm{~S}_{3} \mathrm{Se}_{3}\right)_{1-x} \mathrm{Sn}_{\mathrm{x}}$ thin films [10010-23]

$100101 \mathrm{~K}$ Technology and optical characterization of luminophore coordination compounds Eu(O-MBA) ${ }_{3}$ Phen and NC PEPC/Eu(O-MBA) ${ }_{3}$ Phen [10010-40]

$100101 \mathrm{~L}$ Influence of spray nozzle shape upon atomization process [10010-43]

$100101 \mathrm{M}$ Experimental investigation of micro heat pipe with extra fluid [10010-30]

$100101 \mathrm{~N}$ Studies concerning the effect of large droplets creation during fuel atomization [10010-36]

1001010 Convection's enhancement in thermal micro pipes using extra fluid and shape memory material [10010-28]

$100101 \mathrm{P}$ Heat transfer at the sintered layer-polysynthetic material interface inside heat micro pipes [10010-49]

10010 1Q Heat transfer within a flat micro heat pipe with extra liquid [10010-52]

10010 IR Optical registration of transformer oil absorption processes in electrical pressboard nanocapillaries [10010-72]

\section{Part Two}

10010 is Impedance of $(\mathrm{CoFeZr})_{0,559}\left(\mathrm{PbZrTiO}_{3}\right)_{0,441}$ nanocomposite annealed in a tubular furnace [10010-73]

$100101 \mathrm{~T}$ The influence of strong electric fields on the DC conductivity of the composite cellulose, insulating oil, and water nanoparticles [10010-74]

$100101 \mathrm{U}$ Technological studies for plasmonic metasurfaces [10010-88]

$100101 \mathrm{~V}$ Mechanical action of the transverse spin flows in evanescent fields [10010-95]

10010 IW Nanomaterials and preservation mechanisms of architecture monuments [10010-103]

$100101 X$ Doppler effect in opposite propagating modes of cavity [10010-104]

10010 1Y Analysis of curved shape micro-mirrors for on-chip communication [10010-142] 
MODELING, DESIGN, AND SIMULATION

$1001012 \quad$ Processing in (linear) systems with stochastic input [10010-8]

1001020 Computer fluid dynamics (CFD) study of a micro annular gear pump [10010-10]

$1001021 \quad$ Computer fluid dynamics (CFD) study of a plate heat exchanger working with nanofluids [10010-11]

1001022 3D simulation for solitons used in optical fibers [10010-20]

1001023 On the performance of variable forgetting factor recursive least-squares algorithms [10010-25]

1001024 Considerations about optimization of the flow into a blending tank [10010-27]

1001025 Simulation of nonlinear electron dynamics in tetramer metal-carbon nanoclusters [10010-53]

1001026 Experimental researches of marine wave parameters in the Black Sea Basin [10010-55]

1001027 The analysis of MAI in large scale MIMO-CDMA system [10010-57]

$1001028 \quad$ Noise analysis in power distribution systems [10010-58]

1001029 High performance genetic algorithm for VLSI circuit partitioning [10010-59]

10010 2A Time-frequency analysis of transient signals in power distribution systems [10010-60]

10010 2B Supercharging an internal combustion engine by aid of a dual-rotor bi-flux axial compressor [10010-63]

$100102 \mathrm{C}$ Influence of the cooling degree upon performances of internal combustion engine [10010-65]

$100102 \mathrm{D} \quad$ Quality engineering tools focused on high power LED driver design using boost power stages in switch mode [10010-68]

$100102 \mathrm{E} \quad$ Modeling of the thermal comfort in vehicles using COMSOL multiphysics [10010-97]

$100102 F \quad$ Bistability properties of magnetic micro-nanowires [10010-94]

10010 2G Mathematical modeling and simulation of a thermal system [10010-100]

$100102 \mathrm{H} \quad$ Investigation of electromagnetic couplings between planar open-loop triangular-shaped resonators in microstrip and in multilayer technologies [10010-102]

$1001021 \quad$ Management system to a photovoltaic panel based on the measurement of short-circuit currents [10010-110]

10010 2J PLM in the context of the maritime virtual education [10010-111] 
$100102 K \quad$ Storing wind energy into electrical accumulators [10010-114]

10010 2L Environments for online maritime simulators with cloud computing capabilities [10010-118]

$100102 \mathrm{M} \quad$ Avoiding the parametric roll [10010-120]

$100102 \mathrm{~N}$ Destructive effects induced by the electron beam in scanning electron microscopy [10010-64]

1001020 Original data preprocessor for Femap/Nastran [10010-32]

$100102 \mathrm{P}$ Original analytic solution of a half-bridge modelled as a statically indeterminate system [10010-34]

$100102 \mathrm{O}$ Original analytical model of the hydrodynamic loads applied on the half-bridge of a circular settling tank [10010-37]

$100102 R \quad$ Natural ways to improve the power factor [10010-132]

$1001025 \quad$ Using frequency converter for commanding and controlling for the rotational speed of an AC motor which acting a motor-propeller group [10010-133]

10010 2T Developing smart lighting LED-based device by using light parameterization and control method [10010-130]

$100102 \mathrm{U} \quad$ Analysis and simulation of industrial distillation processes using a graphical system design model [10010-138]

$100102 \mathrm{~V} \quad$ Numerical system for monitoring pressurized equipment [10010-140]

10010 2W A new approach in the development of quality management systems for (micro)electronics [10010-144]

$100102 X \quad$ Study of improving artificial lighting in industrial environments [10010-128]

$100102 Y \quad$ Electrical and optical evaluation aspects of public lighting systems [10010-146]

$100102 Z$ Comparative studies on dimming capabilities of retrofit LED lamps [10010-149]

1001030 E-learning platform for automated testing of electronic circuits using signature analysis method [10010-153]

1001031 Measurement strategy and analytic model to determine firing pin force [10010-154]

1001032 Harmonic distortions measured on board of a maritime vessel [10010-157]

1001033 Streamlining the functioning of the FSO systems by choosing the optimal transmission/ reception components [10010-160]

1001034 Parameter extraction of an organic solar cell using asymptotic estimation and Lambert W function [10010-165] 
OPTICS-INSPIRED APPROACHES FOR NON-OPTICAL APPLICATIONS: SYSTEMS, DEVICES, AND SIGNAL PROCESSING

1001035 Propagation models for non-line-of-sight scenarios [10010-17]

1001036 Antenna gain measurements in the intermediate-field zone [10010-75]

1001037 Autonomous robotic platforms for locating radio sources buried under rubble [10010-76]

1001038 A synthesis approach for antennas with a quasi-linear gain variation over a wide frequency range [10010-90]

1001039 A RF time domain approach for electric arcs detection and localization systems [10010-96]

10010 3A Development and testing of an audio forensic software for enhancing speech signals masked by loud music [10010-119]

10010 3B Steganographic embedding of a secret message in a video flow [10010-145]

\section{PLASMA METHODS AND DIAGNOSTICS USED FOR SURFACE TREATMENTS}

10010 3C Biofouling development on plasma treated samples versus layers coated samples [10010-47]

10010 3D Evolution of the construction and performances in accordance to the applications of nonthermal plasma reactors [10010-99]

10010 3E Effects of GlidArc plasma treatment on metallic surface [10010-106]

10010 3F Long thermal interactions of PAW with normal tooth structure and different dental biomaterials [10010-164]

$100103 G$ Treatment by gliding arc of epoxy resin: preliminary analysis of surface modifications [10010-167]

\section{MEDICAL OPTOELECTRONICS}

$100103 \mathrm{H} \quad$ Ionization pattern obtained in electrospray ionization or atmospheric pressure chemical ionization interfaces for authorized antidepressants in Romania [10010-122]

1001031 Method for the determination of cobalt from biological products with graphite furnace atomic absorption spectrometer [10010-129]

10010 3J Optoelectronic method for determining platinum in biological products [10010-162] 
ADDITIONAL PAPER

10010 3K Terpolymer polyrotaxanes: a promising supramolecular system as electron-transporting materials for optoelectronics [10010-21] 


\section{Authors}

Numbers in the index correspond to the last two digits of the seven-digit citation identifier (CID) article numbering system used in Proceedings of SPIE. The first seven digits reflect the volume number. Base 36 numbering is employed for the last two digits and indicates the order of articles within the volume. Numbers start with 00, 01, 02, 03, 04, 05, 06, 07, 08, 09, 0A, 0B...0Z, followed by 10-1Z, 20-2Z, etc.

Acomi, Nicoleta, 2M

Ahmad, Mohammad Ayaz, $2 U$

Ailincăi, Luminița Iuliana, 3F

Algiu, Madalina, 39

Anchidin, Liliana, 35, 36, 37, 39

Ancuța, Cristian, $2 \mathrm{M}$

Andrei, Cristian, $2 M$

Angelsky, O. V., 05, $1 \mathrm{~V}$

Anton, IUlia-Alina, 24, 26

Apostol, Adela, 02

Araújo, João Pedro, OE

Astanei, D., 3D, 3E

Axinte, Tiberiu, 11, 12

Bacis, Irina Bristena, 17

Bacivarov, Angelica, 2W, 30

Bacivarov, loan C., 2W, 30

Badalan (Draghici), Niculina, 19

Banu, M. A., 2N

Baranov, S. A., 16, 25, 2F

Bărar, Ana, 34

Barca, Cristian, OU

Barhalescu, Mihaela, 2P

Bari, Farida, 36

Bazgan, Sergiv, $1 \mathrm{X}$

Beiu, Roxana Mariana, 1 Y

Bendiksen, Oddvar O., 02

Beniuga, Marius, 14, 1L, $1 \mathrm{~N}$

Berceanu, Madalina-Georgiana, 27

Bita, Bogdan I., 1U, 2N

Boca, Maria Loredana, 2U, 2V

Boiko, Oleksandr, OF, IS

Bojan, M., 10

Bondar, Oleksandr, OE

Bondariev, Vitalii, $\mathrm{OC}$

Bordian, Olga, $1 \mathrm{~K}$

Bostănaru, Andra-Cristina, 3F

Boştină, Alina, 2M

Boştină, Aurel, 2M

Branzei, Mihai, 0J

Brezeanu, G., 06

Brisset, J. L., 3D

Bucurica, Ioan Alin, 1W

Butca, Cristina, 13

Buturuga, Alexandru, ow

Călimănescu, loan, 20, 21

Candel, I., 04

Caragea, Genica, 3I, 3J

Carja, Ionela-Daniela, OG

Caruntu, George, OX
Chilibon, Irinela, $1 \mathrm{H}$

Ciornea, V. I., OP

Ciucur, Violeta-Vali, 2R, 2S

Cochet, V., 3G

Codescu, M. M., 16

Codreanu, Norocel, $2 Z$

Colțuc, Daniela, 11

Constantinescu, Rodica, OW

Craciun, Alexandru, OS

Cretu, Alexandru, 13

Crudu, Andra Manuela, $\mathrm{OH}$

Cucu, Traian C., OJ

Culeac, Ion, $1 \mathrm{~K}$

Czarnacka, Karolina, OB

Damian, Cristian, 11

Damian, V., OY, 10

Dănilă, Octavian, 34

Danisor, Alin, 07, 0X, 28, 2A, 36, 37

Dănişor, Cosmin, $\mathrm{OZ}$

Dascalescu, Anca-Elena, 2Q

Datcu, Mihai, $\mathrm{OZ}$

Datcu, Octaviana, 3B

Deacu, Daniela, 36, 38, 39

Diaconu, Bogdan, OT

Digulescu, A., 04

Dinescu, Adrian, $1 U$

Dinescu, D., 00

Dinu, Simona, 29

Dobra, Remus, 2U, 2V

Dobre, Robert Alexandru, 0I, 18, 1D, 3A, 3B

Dordea, Stefan, 32

Dordescu, Marian, 2I, 2K, 2R

Doroftei, Mirela, 3F

Drăghici, F., 06

Drăgulinescu, Ana-Maria Claudia, 12

Drumea, Andrei, 19, 1B, 1D, 1E

Dubolazov, A. V., OL, OM, ON

Dulamă, loana Daniela, IW

Duma, Virgil-Florin, IY

Dumitrache, C. L., 3C

Dumitrascu, Ana, 0X, 36

Elisei-lliescu, Camelia, 23

Enachescu, M., 00

Enaki, Nicolae A., OK, OQ, IX

Erdodi, G. M., 2K

Exnar, P., 3C

Farcas, A., 09, 3K

Farcas, F., 09, 3K

Faubert, F., 3G 
Feies, Valentin, OS

Felea, C., 3D, 3E

Fierăscu, Irina, IW

Fierăscu, Radu-Claudiu, IW

Fleaca, C., 10

Forje, Mărgărita, 3J

Fratu, Octavian, OU, 12, 13

Frunzulica, Rodica, 2G

Garoi, Florin, 11

Gavrila, Camelia, 2E, 2G

Gavriloaia, Bogdan, OU

Gherghina, Cătălina, 2W, 30

Ghita, S., 3C

Ghilezan, Alin, OV

Goncharov, Alexander A., OD, OF

Gorinchoy, N. N., 25

Gorsky, M. P., OL

Grecu, Iulia, 3H, 3J

Grădinariu, Andrei Cristian, 2B, 2C

Grosu, Neculai, OS

Halunga, Simona, OU, 12, 27

Hanzu-Pazara, Radu, $2 S$

Hnatiuc, B., 3C, 3D, 3E, 3G

Hnatiuc, Eugen, 3D, 3E, 3F

Hnativc, Mihaela, OT, OV, 3C Horhotă, Luminița, 3H

laseniuc, O. V., 0O, OP, $1 \mathrm{~J}$

lleana, loan, 2D, 2T, 2X

loana, C., 04

Ion, Mihaela-Lucia, IW

Ion, Rodica-Mariana, IW

Ionescu, Ciprian, 0I, 17, $2 \mathrm{Z}$

Ionică, Mihai, 3H, 3l, 3J

Iov, Cătălin J., OT

IovU, Mihail S., 0O, OP, $1 \mathrm{~J}, 1 \mathrm{~K}$

Ivansky, D. I., IV

Jenaru, Andreea, 25

Jeníková, Zdenka, 03

Kanarovskii, E. Yu., 16, 25, 2F

Kierczyński, Konrad, $1 T$

Kilpatrick, James, 02

Kołtunowicz, Tomasz N., OD

Komarov, Fadei F., OB

Kravchenko, Yaroslav O., OF

Kurt, Ünal, $2 Y$

Kusko, Cristian, $1 \mathrm{U}$

Lakusta, I. I., OM, ON

Lazar, Iulian, OV

Lesenciuc, loan, 1C, 31

Logofătu, Petre C., OR, OY, 11

Lupan, E. V., OP

Macovei, Radu Alexandru, 3J

Makhavikou, Maksim A., OB

Maksymyak, A. P., IV

Maksymyak, P. P., IV

Mănăilă-Maximean, Doina, 34

Manea, Adrian, OS

Manea, Viorel, 33

Mara, Constantin, OU

Marc, Gheorghe, 2D, 2T, 2X, 2Y
Marcu, Alina E., 18, 1B

Marcu, loana, 12

Mareș, Mihai, 3F

Mares, M., 3D

Marghescu, Cristina, 17, 1E

Markov, Vladimir, 02

Melenko, S. R., ON

Mihai, loan, 15, 1L, 1M, 1N, 1O, 1P, 1Q, 2B, 2C

Militaru, Nicolae, $2 \mathrm{H}$

Mîtă, Carmen, $\mathrm{OH}$

Mnerie, Corina, IY

Moldovan, Lucian, 2V

Muntean, Maria, $1 \mathrm{~A}$

Năstasă, Valentin, 3F

Nedelcu, Elena, $2 R$

Negrescu, Cristian, 3A

Negroiu, Rodica, $2 Z$

Nováček, Vojtěch, 03

Novakovskaya, O. Yu., OL, ON

Nutu, Catalin Silviu, 11, 12

Oanta, Emil M., 07, 2J, 2O, 2P, 2Q

Olar, O. I., OM

Olar, O. V., OL

Opielak, Marek, OE

Paleologu, Constantin, 23

Panait, Cornel, 2O, 2P

Panaitescu, Fanel-Viorel, 24, 26

Panaitescu, Mariana, 24, 26

Pasca, Roxana-Diana, OA

Pasculescu, Dragos, 2U, 2V

Paun, Mirel, 36, 37, 39

Pellerin, N., 3G

Pellerin, S., $3 G$

PetresCU, D. I., 2K

Petrescu, Teodor, 35, 37, 38, 39

Petrică, Gabriel, 30

Pislari, Tatiana, $0 Q$

Plotnikov, Sergei V., OF

Plotog, loan, 0J, 1B

Popescu, Anca, OZ

Popescu, Marian C., 1U, 2N

Postolnyi, Bogdan, OE

Prydiy, O. G., OM, ON

Puşcoci, Sorin, 33

Racz, Csaba Pal, OA

Racz, Levente Zsolt, OA

Radu, Adrian, IW

Radu, Simona, 3H, 3I, 3J

Raicu, Alexandra, 2J, 2L, 2O, 2P

Raicu, Gabriel, $2 \mathrm{~L}$

Regnier, E., 3G

Resmerita, A.-M., 09, 3K

Riabyi, P. A., 05

Risteiu, Mircea, 2D, 2T, 2X

Rogalski, Przemysław, OE, IR

Roşca, Irina, 3F

Rotar, Corina, $1 \mathrm{~A}$

Rotaru, A., 09

Rusu, I., 06

Sabau, Adrian, 2Q, 3C 
Sakhnovskiy, M. YU., OL, OM, ON

Santa, Szabolcs, OA

Schiopu, Paul, OR, OS, 22

Serbanescu, lonut, OX

Serbezeanu, Diana, OG

Sibiescu, Doina, $\mathrm{OH}$

Sidor, M., OL, OM

Sima, Adrian, OR

Soltys, I. V., OL

Špatenka, Petr, 03, 3C

Sprinceana, Siviu, $1 \mathrm{M}, 10,1 \mathrm{P}, 1 \mathrm{Q}$

Stan, Liviu-Constantin, 20, 21

Stanciu, Mihai, 3B

Stanomir, Dumitru, 3A

Ştirbescu, Raluca-Maria, IW

Stoica, I., 3E

Stoichescu, Dan Alexandru, OW, 33

Suciu, Cornel, 14, 15, 1C, 31

Suciu, George, 13

Suciu, Victor, 13

Şuică-Bunghez, loana-Raluca, IW

Sultan, Carmen, 3H

Svasta, Paul, 19, 1F

Tamas, Razvan, 07, 0X, 23, 35, 36, 37, 38, 39

Tasu, Antonio Sorin, 35, 36, 37, 38

Tebeica, C. M., 22

Teodorescu, L., 06

Teodorescu, Sofia, IW

Ticu, Ionela, OX

Toma, Petrica D., 2G

Tomescu, Roxana M., 1U, 2N

Toropoc, Mirela, 2G

Truță, Elena, 3H

Tulbure, Adrian, 1A, 2 Y

Udrea, Cristian, 11

Ursache, M., 3D, 3E

Ursu, Laura, 3F

Ushenko, A. G., OL, OM, ON

Ushenko, V. A., OL, OM, ON

Ushenko, Yu. A., OL, OM, ON

Vacková, Tat'ana, 03

Vartires, Andreea, 2E

Varzaru, Gaudentiu, 0J

Vasile, Alexandru, 17, 22

Vasile, C., 04

Vasile, F., 22

Vasile, T., OY, 10

Vasiliu, Ana Lavinia, 3F

Verlan, Victor, $1 \mathrm{~K}$

Vidrascu, Mihai G., $1 \mathrm{~F}$

Viscol, Oana, 3H, 3J

Vizireanu, Radu, OU

Vizitiu, Mihaela, $\mathrm{OH}$

Vlad-Bubulac, Tăchiță, OG

Vlădescu, Marian, 08, 0S, 18, 1F, 1G, 22, 34,

$3 \mathrm{H}, 3 \mathrm{I}, 3 \mathrm{~J}$

Voicu, Carmen, 27

Vuza, Dan Tudor, 08, $1 \mathrm{G}$

Wartel, M., 3G

Yaltychenko, O. V., 16, 25, 2F
Yerdybaeva, Nazgul K., OF

Yunda, Andrey N., OD, OF

Zamfir, Oana-Liliana, 31

Zburlea, Elena, 2R, 32

Zenkova, C. YU., 05, 1V

Zhytaryuk, V. G., OL

Zubareva, Vera, $1 \mathrm{~K}$

Żukowski, Paweł, $1 \mathrm{~T}$ 
Proc. of SPIE Vol. 10010 1001001-14

Downloaded From: https://www.spiedigitallibrary.org/conference-proceedings-of-spie on 26 Apr 2023 Terms of Use: https://www.spiedigitallibrary.org/terms-of-use 


\section{Conference Committees}

Steering Committee

Paul Schiopu, Conference Chair, Politehnica University of Bucharest (Romania)

Cornel Panait, Conference Co-chair, Maritime University of Constanta (Romania)

Violeta-Vali Ciucur, Technical Program Co-chair, Maritime University of Constanta (Romania)

Razvan Tamas, Technical Program Co-chair, Maritime University of Constanta (Romania)

Ionica Cristea, Conference General Manager, Politehnica University of Bucharest (Romania)

Marian Vlădescu, Conference Executive Manager, Politehnica University of Bucharest (Romania)

International Committee

Oleg Angelsky, National University of Chernovtsy (Ukraine)

Erchin Serpedin, Texas A\&M University (United States)

Yury A. Ushenko, National University of Chernovtsy (Ukraine)

Mircea Guina, Tampere University of Technology (Finland)

Dan Cojoc, National Institute for Physics of Matter, TASC-INFM Trieste (Italy)

Daniela Reyna, LAAS-CNRS INSA, Toulouse (France)

Philippe Arguel, LAAS-CNRS INSA, Toulouse (France)

Radu Malureanu, Technical University of Denmark (Denmark)

Luige Vladareanu, Romanian Academy, Bucharest (Romania)

Alexandru Stancu, "Alexandru loan Cuza" University, lasi (Romania)

Dan Apostol, National Institute for Laser Plasma and Radiation Physics (Romania)

Henri Arsenault, Laval University (Canada)

Paul Schiopu, Politehnica University of Bucharest (Romania)

Marin Dragulinescu, Politehnica University of Bucharest (Romania)

Gheorghe Gavriloaia, University of Pitesti (Romania)

Raluca Muller, National Institute for R\&D in Microtechnologies - IMT, Bucharest (Romania)

Ileana Cernica, National Institute for R\&D in Microtechnologies - IMT, Bucharest (Romania)

Dana Cristea, National Institute for R\&D in Microtechnologies - IMT, Bucharest (Romania)

Eugene Curatu, Alcon Laboratories (United States)

Valeriu Dorogan, Technical University of Moldova, Chishinev (Moldova)

Ioan Ileana, University of Alba-Iulia (Romania) 
Mihail lovu, Institute of Applied Physics (Moldova)

Adrian Manea, Politehnica University of Bucharest (Romania)

Niculae Puscas, Politehnica University of Bucharest (Romania)

Constantin Grigoriu, National Institute of Laser Plasma and Radiation

Physics (Romania)

Alexandru Vasile, Politehnica University of Bucharest (Romania)

loana Armas, "Hyperion" University of Bucharest (Romania)

Cornel Panait, Maritime University of Constanta (Romania)

Violeta-Vali Ciucur, Maritime University of Constanta (Romania)

Razvan Tamas, Maritime University of Constanta (Romania)

Victor Ciupina, Maritime University of Constanta (Romania)

George Caruntu, Maritime University of Constanta (Romania)

Vasile Sarbu, "Ovidius" University of Constanta (Romania)

Mihaela Cezarina Hincu, "Ovidius" University of Constanta (Romania)

Rodica Mehedinti, "Ovidius" University of Constanta (Romania)

Lucian Balut, Maritime University of Constanta (Romania)

Emil Oanta, Maritime University of Constanta (Romania)

Dan Popa, Maritime University of Constanta (Romania)

Alin Danisor, Maritime University of Constanta (Romania)

Mihaela Hnatiuc, Maritime University of Constanta (Romania)

Cornel loana, GipsaLab/Université de Grenoble (France)

Gabriel Vasile, GipsaLab/CNRS (France)

Marian Vlădescu, Politehnica University of Bucharest (Romania)

Neculai Grosu, Politehnica University of Bucharest (Romania)

Nicolae Militaru, Politehnica University of Bucharest (Romania)

Alexandru Craciun, Politehnica University of Bucharest (Romania)

Florin Garoi, National Institute for Laser Plasma and Radiation Physics,

Bucharest (Romania)

Victor Damian, National Institute for Laser Plasma and Radiation Physics,

Bucharest (Romania)

Dana Granciu, Romanian Institute of Optics, Bucharest (Romania)

Ioan Mihai, Stefan cel Mare University of Suceava (Romania)

Sergey Yermolenko, National University of Chernovtsy (Ukraine)

Claudia Yu. Zenkova, National University of Chernovtsy (Ukraine)

Emil Rusu, Institute of Nanotechnologies (Moldova)

Dorin Dadarlat, National Institute for Isotopic and Molecular Technologies,

Cluj-Napoca (Romania)

Ciprian Ionescu, Politehnica University of Bucharest (Romania)

Norocel Codreanu, Politehnica University of Bucharest (Romania)

Mona Mihailescu, Politehnica University of Bucharest (Romania)

loan Plotog, Politehnica University of Bucharest (Romania)

Technical Committee

Marian Vlădescu, Politehnica University of Bucharest (Romania)

Razvan Tamas, Maritime University of Constanta (Romania)

Paul Schiopu, Politehnica University of Bucharest (Romania) 
Ionica Cristea, Politehnica University of Bucharest (Romania) Neculai Grosu, Politehnica University of Bucharest (Romania) Alexandru Craciun, Politehnica University of Bucharest (Romania) Adrian Manea, Politehnica University of Bucharest (Romania) Andrei Drumea, Politehnica University of Bucharest (Romania) Nicolae Militaru, Politehnica University of Bucharest (Romania) Mihaela Hnatiuc, Maritime University of Constanta (Romania) George Caruntu, Maritime University of Constanta (Romania) Ion Ileana, University of Alba Iulia (Romania)

Florin Garoi, National Institute of Laser, Plasma and Radiation (Romania)

Victor Damian, National Institute of Laser,Plasma and Radiation (Romania)

Oleg Angelsky, National University of Chernovtsy (Ukraine) C.Yu. Zenkova, National University of Chernovtsy (Ukraine) Mihail lovu, Institute of Applied Physics, Academy of Sciences of Moldova (Moldova)

Nicolae Enachi, Institute of Applied Physics (Moldova)

Dana Granciu, Romanian Institute of Optics (Romania)

Gheorghe Gavriloaia, University of Pitesti (Romania)

Bogdan Hnatiuc, Maritime University of Constanta (Romania)

Stéphane Pellerin, University of Orleans (France)

Mona Mihailescu, Politehnica University of Bucharest (Romania)

Eugen Scarlat, Politehnica University of Bucharest (Romania)

\section{Local Organizing Committee}

Cornel Panait, Razvan Tamas, Violeta-Vali Ciucur, Gegiana Buzatu, Amalia Diaconescu, George Caruntu, Dan Popa, Ana Dumitrascu, Mirel Paun, Antonio Sorin Tasu, Liliana Achitei, Alexandra Nita, Madalina Dragan,Elena Nedelcu, Milis Nilgun Caibula, Cosmin Danisor

Session Chairs

1 Plenary Session

Cornel Panait, Marian Vlădescu, Razvan Tamas

2 Advanced Materials and New Technologies

Dorin Dadarlat, Aurica Farcas

3 Diffractive, Micro-Optics, and Optical Signal Processing

Mihail lovu, Mihai lonica

$4 \quad$ Microsystems, and Instruments

Octavian Fratu, Cristian Viespe, Paul Schiopu, Adrian Tulbure 
5 Micro/Nanophotonics and Micro/Nanotechnologies

Rodica Mariana Ion, Roxana-Mariana Beiu

6 Modeling, Design, and Simulation

Nicolae Enaki, Alin Danisor, Emil Oanta, Gheorghe Marc,

Octaviana Datcu, Viorel Manea

7 Optics-Inspired Approaches for Non-Optical Applications: Systems, Devices, and Signal Processing

Razvan Tamas, Cornel loana

8 Plasma Methods and Diagnostic Used for Surface Treatments Bogdan Hnatiuc, Petr Spatenka

9 Medical Optoelectronics

Mona Mihailescu, Gabriel Popescu 


\section{Introduction}

The eighth edition of the International Conference on Advanced Topics in Optoelectronics, Microelectronics, and Nanotechnologies (ATOM-N 2016), was hosted for the fifth time in Constanta, Romania, one of the most important academic, cultural, and industrial centers in Romania, located in the historical region of Dobrogea, on the Black Sea (Pontus Euxinus) seaside.

The present edition marks 16 years of ATOM-N conference existence, time in which it has consistently gathered the youthful spirit, as well as the experience of the most appreciated scientists in the field of micro/nano technology and photonics/optoelectronics - topics that have, nowadays, great scientific applications worldwide.

ATOM-N 2016 took place 25-28 August 2016, and was organized into nine main sessions (from which two new special sessions): Plenary Session; Advanced Materials and New Technologies; Diffractive, Micro-Optics, and Optical Signal Processing; Sensors, Microsystems, and Instruments; Modeling, Design and Simulation; Micro/Nanophotonics and Micro/Nanotechnologies; Optics-inspired Approaches for Non-optical Applications: Systems, Devices, and Signal Processing; Plasma Methods and Diagnostics Used for Surface Treatments; and Medical Optoelectronics. This was for the fourth time in the conference history when students contributions have been evaluated and awarded.

We received abstracts from scientists all over Europe and United States (from over six countries). Due to the efforts of the scientific and program committees, 143 papers have been accepted for presentation, from which 127 have been selected for publishing in the conference proceedings as follows: seven invited (plenary) lectures, 38 oral lectures, and 82 poster papers.

We would like to express our thanks to the organizing committee for their enthusiastic and efficient work, and we extend our warmest thanks to all of the authors who presented their scientific contributions.

We hope that all of the participants of this prestigious meeting have had both an interesting professional experience, as well as moments of relaxation, while discovering the multicultural aspects of the academic city of Constanta.

Marian Vladescu
Razvan Tamas
lonica Cristea 
Proc. of SPIE Vol. 10010 1001001-20 Downloaded From: https://www.spiedigitallibrary.org/conference-proceedings-of-spie on 26 Apr 2023
Terms of Use: https://www.spiedigitallibrary.org/terms-of-use 